\title{
The Case of the Phantom Trophoblastic Tumor
}

\section{Benedict BBenigno*}

Director, Gynecologic OncologyNorthside Hospital, Atlanta, Georgia

Submission: June 13, 2018; Published: July 09, 2018

${ }^{*}$ Corresponding author: Benedict B Benigno, Founder and CEOOvarian Cancer Institute, Director, Gynecologic OncologyNorthside Hospital, Atlanta, Georgia, Email: Benedict.Benigno@northside.com

\section{Opinion}

This report provides an insight into a very unusual problem in the first trimester of pregnancy,and describes the unfolding of a series of potential blunders. We all know that most problems in gynecologic oncology become terribly magnified when the patient is pregnant. HB had a routine ultrasound in the first trimester of pregnancy, and a large, extremely vascular mass occupying most of the lower anterior abdominal wall, was found (Figure 1). Because she had received methotrexate two years earlier for a persistent elevation of the hCG titer following surgery for an ectopic pregnancy, she was referred to the gynecologic-oncology service with the working diagnosis of metastatic gestational trophoblastic disease (GTD). An MRI showed a vascular mass in the subcutaneous tissue invading the rectus sheath and muscle, but not attached to the uterus (Figure 2). The report stated, in no uncertain terms, that the mass was strongly indicative of a metastasis from GTD. However, the hCG level was consistent with the estimated gestational age, and a mass such as this would represent an extremely unusual way for this disease to present. She had been told that she would need the have the pregnancy terminated, followed by chemotherapy to reduce the size of the mass prior to its removal.

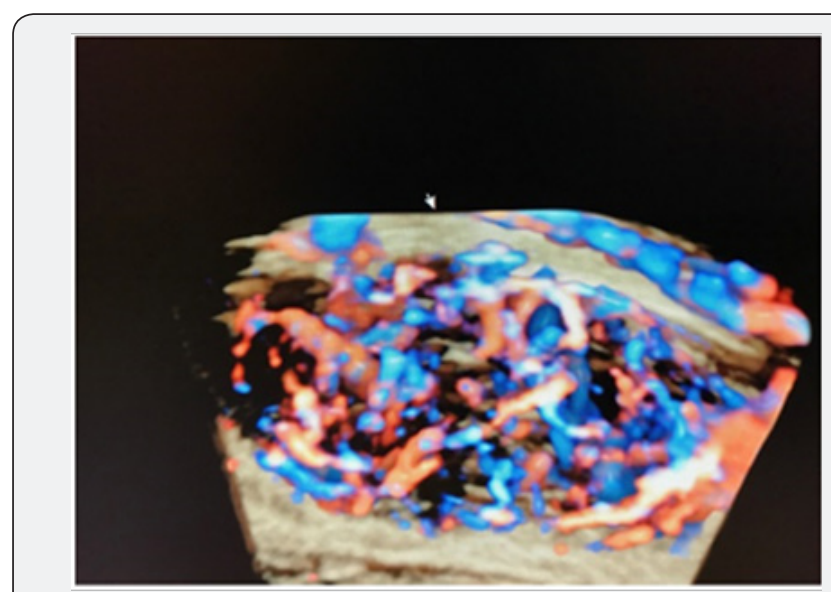

Figure 1: Lower anterior abdominal wall.

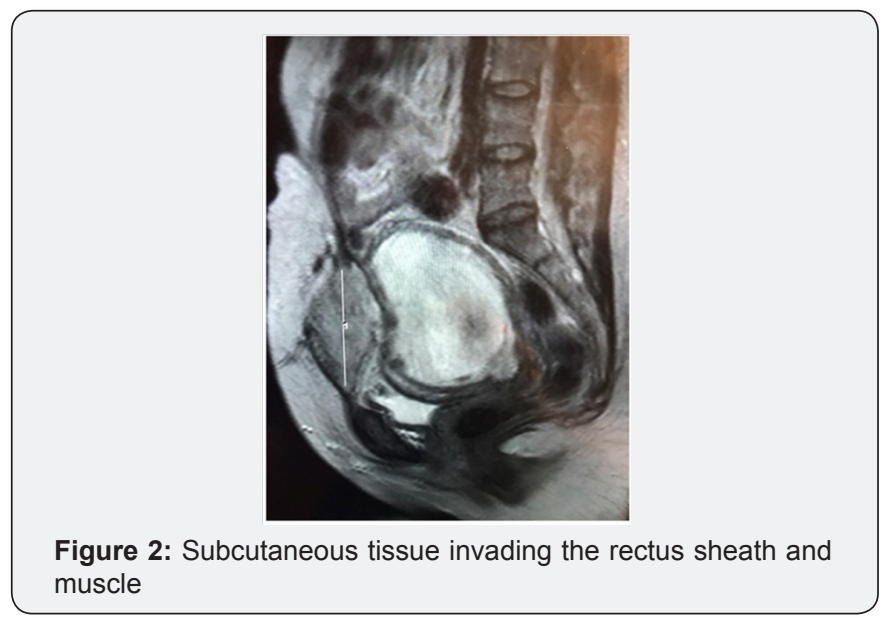

The management of this patient presented several medical and ethical problems. If this mass was the result of GTD, then the pregnancy, which was greatly desired, would need to be terminated as soon as possible, unless, of course, it could be removed while the she was pregnant. She was referred to a general surgeon who refused to remove the mass until after the pregnancy had been terminated, for fear of causing massive hemorrhage. I refused to biopsy it because, if GTD had been the origin of the problem, there would not have been enough blood in the blood bank to compensate for such an error. Chemotherapy in the presence of a pregnancy would be unthinkable. Who would wish to shoulder the burden of terminating such a pregnancy, with the subsequent resection of the abdominal wall mass, only to learn that it was not related to GTD at all, and that the termination had proven to be unnecessary?

Since it is inherent in the very nature of the gynecologiconcologist to go where angels fear to tread, I prevailed upon my junior partner to operate on this patient in the early second trimester of her pregnancy. The operation involved the removal of the lower anterior abdominal wall, including the rectus sheath and muscle. The enormous defect was repaired using 
an acellular dermal matrix. The total blood loss was less than $50 \mathrm{cc}$ 's and she left the hospital in two days without complication. The final pathology report was consistent with endometriosis with extensively decidualized stroma, without evidence of trophoblastic tissue (Figure 3). It should be noted that she recovered more easily from the surgery than from the initial consultation, which advocated the termination of the pregnancy followed by chemotherapy.

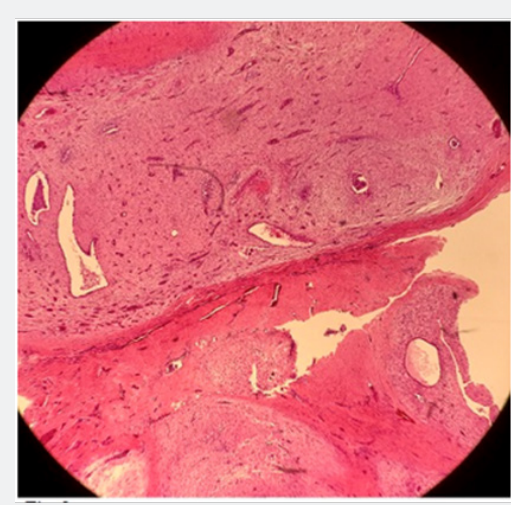

Figure 3: Evidence of trophoblastic tissue.
Gestational trophoblastic disease has an interesting niche in the history of oncology, as it was the first solid tumor to be cured with chemotherapy[1]. It is potentially lethal, but has a very high cure rate, even when there is a recurrence. Most treatment failures are associated with a delay in diagnosis or improper management. These issues weighed heavily on the decision-making process in our approach to her care. GTD is the most vascular of all tumors, especially when the patient is pregnant. For this reason, all precautions were taken to ensure the safe removal of the abdominal wall mass, including the ligation of the inferior epigastric vessels. However, as might be imagined, catastrophic hemorrhage could have accompanied our efforts. I have never forgotten that Napoleon once said that he would much rather have a lucky general than a brilliant one! The patient went on to deliver a very healthy girl whom she named after her surgeon.

\section{References}

1. Li MC, Hertz R, Spencer DB (1956) Effect of methotrexate therapy upon choriocarcinoma and chorioadenoma. Proc Soc Exp Biol Med 93(2): 361-366.

\section{Your next submission with Juniper Publishers will reach you the below assets}

- Quality Editorial service

- Swift Peer Review

- Reprints availability

- E-prints Service

- Manuscript Podcast for convenient understanding

- Global attainment for your research

- Manuscript accessibility in different formats

( Pdf, E-pub, Full Text, Audio)

- Unceasing customer service

Track the below URL for one-step submission https://juniperpublishers.com/online-submission.php 